\title{
Boron Nutrition of Crops in Relation to Yield and Quality- A Review
}

\author{
Dipa Kundu*, Rubina Khanam, Umalaxmi Thingujam, Sushanta Saha and Gora Chand Hazra \\ Department of Agricultural Chemistry \& Soil Science, Bidhan Chandra Krishi Viswavidyalaya, India
}

Submission: August 06, 2016; Published: September 13, 2016

*Corresponding author: Dipa Kundu, Deparment of Agricultural Chemistry \& Soil Science, Bidhan Chandra Krishi Viswavidyalaya, Mohanpur-741252, West Bengal, India.

\begin{abstract}
Boron nutrition of soil and crops has assumed greater importance with the introduction of high yielding crop varieties under intensive cultivation with high use of chemical fertilizers. The availability and transformation of boron in soil, yield and quality of crops have a significant bearing in relation to boron and sulphur nutrition. Use of optimum combination of organic, inorganic and biological nutrient sources in a specific crop, cropping system and climatic situation so as to achieve and to sustain the optimum yield and to improve or to maintain the soil's physical, biological and chemical properties. Such a crop nutrition package has to be technically sound, economically attractive, practically feasible and environmentally safe.
\end{abstract}

Keywords: Boron; Nutrition; Crop yield; Cereals; Legumes; Oilseeds; Sulphur

\section{Introduction}

There have been renewed interests in the use of secondary and micronutrients in crop production in the recent years. The renewed interest is largely due to the wide spread occurrence of their deficiencies from different parts of the country. Significant response of many crops to micronutrient fertilization to the foliage of plants has also been reported by different investigators from almost all the states in our country. Boron fertilization is necessary for improvement of crop yield as well as nutritional quality. Boron is absorbed by roots as un dissociated boric acid $\left[\mathrm{H}_{3} \mathrm{BO}_{3}\right][1,2]$ which has a strong ability to form complexes with diols and polyols, particularly with cis-diols inside the plant system. Among the elements required by plants that are taken up from the soil, B is the only element that is taken up by plants not as an ion, but as an uncharged molecule [2,3]. Boron (B) deficiency has been reported from many mustard growing areas in India. It occurs on deep, highly weathered soils. Boron deficiency is more commonly observed in light textured acidic Entisols and Inceptisols receiving high precipitation [4]. There are numerous reports on the positive response of mustard to B fertilization [5]. India is the fourth largest oilseed economy in the world. Among the seven edible oilseeds cultivated in India, rapeseed-mustard contributes $28.6 \%$ in the total oilseeds production and ranks second after groundnut sharing $27.8 \%$ in the India's oilseed economy.

The availability of the nutrients depends on factors such as $\mathrm{pH}$ of the soil, moisture content, cropping pattern, rate of release of micronutrients from the soil mineral, and the presence of other ions in the soil. Soil $\mathrm{pH}$ is regarded as a major factor regulating $\mathrm{B}$ availability in soils. Increasing $\mathrm{pH}$ favors its retention by soils or soil constituents $[6,7]$.

Boron seems to be a crucial element for the maintenance of structural integrity and protect the plasma membranes against peridoxidative damage [8]. Parr and Loughmann [9] reported that $B$ is involved in sugar transport, cell wall synthesis, lignifications and IAA synthesis and phenol metabolism. Sharma and Tanuja [10] have suggested the involvement of B in stomatal regulation. Boron is an essential micronutrient for plants, but at the same time, its range between deficiency and toxicity is narrower than that of any other element [11]. In black calcareous soil, the soil application of $5.8 \mathrm{~kg} / \mathrm{ha}$ boric acid increased the yield. Only small quantities of boron are needed for optimum production. On sandy soils $0.5-1.0 \mathrm{~kg} / \mathrm{ha}$ boron is sufficient.

Foliar application of boron as low as $0.1 \mathrm{ppm}$ also increased the yield [12]. Sulphur plays an important role in the metabolism of mustard. It is important for the synthesis of proteins. It helps in biological oxidation-reduction processes. It plays an important role in chlorophyll formation. Soils supporting mustard are generally poor in sulphur. On the other hand, acid soils are also deficient in sulphur. The uptake of sulphur from the soil is generally in the form of sulphate.

The availability of sulphur to plants depends on the ability of the soil to supply sufficient soluble sulphate. Wide occurrence 
of sulphur deficiency in the country's soils has been reported. Soils with less than $10 \mathrm{ppm}$ available sulphur are deficient for mustard. S deficient plants have low chlorophyll content. Soil application of $250 \mathrm{~kg} /$ ha gypsum is able to improve the deficiency and increase the seed yield. The deficiency of the nutrients in the plant will bring about derangement in the metabolism, which in turn manifests in the development of visible deficiency symptoms such as yellowing of the leaves, interveinal chlorosis, purpling of the leaves and stems, stunted plant growth and other abnormalities. In the case of deficiency of more than one element, or severity of deficiency, the identification of the symptoms for a given nutrient would be difficult and requires experience.

\section{Status of available B in soils of India}

Available B content of Indian soils ranges from just traces to $8 \mathrm{mg} / \mathrm{kg}$ soil. Its deficiency mainly occurs in acidic alluvial soils, red and lateritic soils of West Bengal, Orissa, Meghalaya and Madhya Pradesh, calcareous, alluvial and red-yellow soils of Bihar, acidic soils of Assam and to a lesser magnitude in other state. The available B content in soils decreases with increasing depth. Such decrease is attributed to the decrease in organic $C$ and clay content of the soils at lower depths $[13,14]$.

\section{Effect of Organic Manure on the Availability of B in the Soil}

One of the comprehensive studies to assess the influence of soil organic matter on available boron content was done by Berger and Troug [15]. They reported an apparent correlation between organic matter and availability of boron in acid soils. Correlation coefficients between organic matter and available boron in both virgin and cultivated surface samples were highly significant. They also reported that available boron decreased with increasing acidity probably due to the fact that organic matter also decreased with increasing acidity. With the removal of organic matter, clay fixed the most boron and rendered it unavailable to the plants [16].

The magnitude of boron retention by the humus system and the chemical reaction between boron and di-hydroxy organic compound suggested that boron unites with 'favorable' diols of the organic matter or those which are gradually released as intermediates of the microbiological breakdown of organic matter in a soil [17]. Large part of the boron in soil is held in organic matter in tightly bound compounds that had been found in the growing plants themselves and the boron in organic matter was largely released in available form through the action of microbes [15].

A laboratory incubation experiment was conducted to study the influence of organic matter and lime application on the recovery of added boron (B) by four different extractants (hot$\mathrm{CaCl} 2$, mannitol- $\mathrm{CaCl}_{2}$, tartaric acid, and ammonium acetate) in two B-deficient acid alluvial soils. Soils were brought to four relatively constant $\mathrm{pH}$ and three organic matter levels before application of B. Both liming (from pH 4.8 to 6.8) below neutrality and organic matter application increased such recovery of added $B$ in all the extractable forms. The effect being more pronounced in fine- textured than in coarse-textured soils. Complexation of added B and coating of the surfaces of Fe- and Al-oxides by soluble organic compounds are suggested as the possible reasons for such increased recovery of added B in soils [4].

\section{Influence of Organic Manure, Sulphur and Boron on the Yield Parameters}

To produce optimum yield, mustard needs the application of secondary and micronutrient fertilizer from outside. There is growing awareness that secondary and micronutrients may limit mustard yield even though they are required in small amounts by plants. Pulses and oilseeds gave higher economic response as compared to cereals. The response of chickpea to boron application varied from 167 to $182 \mathrm{~kg} \mathrm{ha}^{-1}$ with $2 \mathrm{~kg}$ $\mathrm{B} \mathrm{ha}^{-1}$ except in severely deficient sites where it was $3 \mathrm{~kg} \mathrm{ha}^{-1}$ [18]. Boron increased the seed yield of sesamum and mustard varieties at application rates of 1.5 and $2.5 \mathrm{~kg} \mathrm{~B} \mathrm{ha}^{-1}$ [19]. Boron applied as boric acid increased the plant height, relative growth rate, and net assimilation rate and leaf area index in pigeon pea [20]. Combined application of micronutrients like Zn, Mn, Fe and $B$ produced highest fruit yield with reduced cracking of fruits of tomato. This might be due to increasing RNA and DNA contents in reproductive tissues in the presence of $\mathrm{Zn}$ and $\mathrm{B}$ which may enhance the flower bud initiation and fruit setting [21].

An experiment was conducted to evaluate the various levels of B on yield of PKM 1 variety of tomato. The results revealed that the highest fruit yield of $33 \mathrm{tha}^{-1}$ was recorded in treatment that received borax @ $20 \mathrm{~kg} \mathrm{ha}^{-1}$ and was found to be significantly superior to rest of the treatments $\left(0,5,10,15\right.$ and $\left.25 \mathrm{~kg} \mathrm{ha}^{-1}\right)$. The yield increase was about 33.6 per cent over control [22]. In acid soils of Orissa, application of B at $2 \mathrm{~kg} \mathrm{ha}^{-1}$ to groundnut gave yield response of about 29.9 percent. In B deficient acid sedentary soils having $0.3 \mathrm{~kg} \mathrm{ha}^{-1}$ of hot water soluble boron at Ranchi, groundnut responded significantly to boron application and pod yield increased remarkably from $1140 \mathrm{~kg} \mathrm{ha}^{-1}$ in control to $1530 \mathrm{~kg} \mathrm{ha}^{-1}$ with $3 \mathrm{~kg} \mathrm{~B} \mathrm{ha}^{-1}$. However $4.5 \mathrm{~kg} \mathrm{ha}^{-1}$ reduced pod yield in groundnut [23].

Foliar application of 100 ppm of boric acid three times viz., 40, 50, 60 days after sowing produced significant improvement in growth parameters of tomato which might be due to the enhanced photosynthetic activity and metabolic activity with the application of B [24]. Grain yield of soybean for combined application of boron + sulphur treatment was $1.77 \mathrm{t} \mathrm{ha}^{-1}$ while it was only $1.40 \mathrm{tha}^{-1}$ in control. Grain yield of the following wheat crop was $3.7 \mathrm{t} \mathrm{ha}^{-1}$ in treated plots while control plot yielded 2.7 t ha-1 of wheat grain [25].

Application of 1.0 to $2.0 \mathrm{~kg} \mathrm{~B} /$ ha significantly influenced the seed yield of mustard varieties over control. Dhali x two $\mathrm{kg}$ of boron produced the highest seed yield (1610 kg/ha) which was 
statistically similar to Dhali x one $\mathrm{kg}$ of boron $(1557 \mathrm{~kg} / \mathrm{ha})$. So from the economic point of view, one $\mathrm{kg}$ of boron per hectare may be recommended for mustard production at Rangpur region [26]. A field experiment was conducted during the 2001-03 winter seasons in New Delhi, India, to study the effects of three phosphorus levels $\left(0,25\right.$ and $\left.50 \mathrm{~kg} \mathrm{P}_{2} \mathrm{O}_{5} / \mathrm{ha}\right)$, three sulfur levels $(0,20$ and $40 \mathrm{~kg} \mathrm{~S} / \mathrm{ha}$ ) and two boron levels (control and $0.2 \%$ spray of borax at $50 \%$ flowering) on rainfed Indian mustard (Brassica juncea cv. Pusa Barani). Progressive increase in phosphorous and sulphur levels increased the yield attributes and seed yield, but the increase in seed yield was significant only up to $25 \mathrm{~kg}$ P205/ha and $20 \mathrm{~kg} \mathrm{~S} / \mathrm{ha}$. Indian mustard removed more sulphur than phosphorous [27].

A field experiment conducted on a typical boron deficient entisols where mustard, wheat and potato were the test crops showed that the application of boron increased both the height of mustard plants and also its 1,000 grain weight over the control. Such increase in seed size was higher with split application of boron either to soil or as foliar sprays than single application showed that significant effect of boron on yield of the mustard [28]. An experiment conducted on the mustard variety BARI Sarisha-8, (Brassica. napus group) revealed that boron and nitrogen concentrations of grain and stover were significantly increased with increased rate of boron application indicating that boron had positive role on protein synthesis. The grain boron concentration increased from $19.96 \mu \mathrm{g} / \mathrm{g}$ in boron control to $45.99 \mu \mathrm{g} / \mathrm{g}$ and $51.29 \mu \mathrm{g} / \mathrm{g}$ due to application of $1 \mathrm{~kg}$ and $2 \mathrm{~kg}$ $\mathrm{B} / \mathrm{ha}$, respectively [5].

Field experiments were conducted at College of Agriculture, Indore, Jawaharlal Nehru Krishi Viswavidyalaya, Jabalpur, during kharif 2007 and 2008 to study the effect of sulphur and boron fertilization on yield attributes and yield of soybean. The experiment was laid out in a factorial combination of $\mathrm{S}$ and $\mathrm{B}$ following factorial randomized block design replicated thrice. There were 25 treatment combinations consisting of five rates of both $\mathrm{S}(0,10,20,30$ and $40 \mathrm{~kg} \mathrm{~S} / \mathrm{ha})$ and $\mathrm{B}(0,0.5,1.0,2.0$ and $4.0 \mathrm{~kg} \mathrm{~B} / \mathrm{ha}$ ). The results of the experiments revealed that application of $30 \mathrm{~kg} \mathrm{~S} / \mathrm{ha}$ recorded better yield attributes viz., branches/plant, pods/plant, seeds/pod and 100-seed weight and higher yield than the other treatments. Similarly, application of boron at $1.0 \mathrm{~kg} / \mathrm{ha}$ recorded better yield attributes and higher yield of grain and straw [29].

Studies on interactions between boron (B) and sulfur (S) on yield and yield components of canola in a calcareous soil showed that the interaction between boron and sulphur was significant on yield of dry matter, grain yield, oil and protein yields. The highest grain yield of canola (3002.4 kg ha) was observed when $2.5 \mathrm{~kg} \mathrm{~B}$ and $800 \mathrm{~kg} \mathrm{~S}$ ha were applied [29]. Application of sulphur $@ 30 \mathrm{~kg}$ ha and boron @ $2.5 \mathrm{~kg}$ ha along with the recommended dose of nitrogen, phosphorous and potassium resulted in better grain yield $1460 \mathrm{~kg} / \mathrm{ha}[30,31]$.

\section{Influence of $B$ and $S$ on the Increased Nutrient Concentration and their Uptake}

Sulphur application significantly increased the nitrogen, phosphorous and sulphur content and their uptake by mustard in an alluvial soil at Varanasi [29]. The positive interaction between sulphur and boron under field condition has been reported in groundnut. In an experiment conducted on a soil deficient in sulphur and boron in Maharashtra, the two nutrients interacted positively. The interaction effect was more pronounced on oil yield than on the kernel yield. There were several instances where boron and sulphur applications are recommended for oilseeds [32].

Application of sulphur increased the total uptake of nitrogen, phosphorous and sulphur by 55.4, 43.5 and 80.2 percent respectively compared to control (without sulphur). Nitrogen uptake increased significantly up to $40 \mathrm{~kg}$ sulphur while phosphorous and sulphur increased up to $20 \mathrm{~kg} \mathrm{~S}$ per hectare. A field experiment was conducted by Sud et al. [33] which showed that the grain sulphur and boron uptake showed significant variation on the application of different levels of sulphur and boron. The highest sulphur and boron uptake were found when sulphur was applied @ 10 and $20 \mathrm{~kg} \mathrm{ha}^{-1}$ respectively and lowest uptake were obtained from no sulphur application. On the other hand, the highest boron and sulphur uptake was achieved by the application of 2.0 and $4.0 \mathrm{~kg}$ ha1 [34]. Interaction effect between boron and sulphur significantly and synergistically influenced the dry matter and seed yields of both the crops (sunflower and mustard) which were observed the highest at $60 \mathrm{mg} \mathrm{kg}^{-1}$ of $\mathrm{S}$ in conjunction with $2 \mathrm{mg} \mathrm{kg}^{-1}$ of boron. The oil and protein contents of sunflower and mustard were significantly and synergistically improved by the application of both sulphur and boron [35].

Leaf boron concentration increased as boon application was increased. Similarly, it has been reported that boron concentration in shoot and root of canola increased with increasing boron application. A significant interaction between boron and sulphur led to the highest leaf boron concentration at rate of $10 \mathrm{~kg} \mathrm{~B}$ and $800 \mathrm{~kg} \mathrm{~S} \mathrm{ha}^{-1}$. The highest leaf boron content observed in treatment of $10 \mathrm{~kg} \mathrm{~B}$ and $800 \mathrm{~kg} \mathrm{~S} \mathrm{ha}^{-1}$ which was due to the high leaf boron concentration [30]. Boron had significant variation in relation to boron uptake by soybean. The highest boron uptake $(0.135 \mathrm{~kg}$ per hectare) was achieved by the application of $1.5 \mathrm{~kg}$ boron per hectare and the lowest $(0.044 \mathrm{~kg}$ per hectare) from control. In this study it might be concluded that boron uptake was influenced by boron application. The increase in uptake may be due to the increase in level of boron application in the field and high grain yield [36].

A field experiment was conducted during rabi season of 200809 and 2009-10 at the Students' Instructional Farm, Chandra Shekhar Azad University of Agriculture \& Technology, Kanpur to evaluate the effect of sulphur $(0,20,40$ and $60 \mathrm{~kg} \mathrm{~S} / \mathrm{ha})$, zinc $(0$, 5 and $10 \mathrm{~kg} \mathrm{Zn/ha)} \mathrm{and} \mathrm{boron} \mathrm{(0,} 0.5$ and $1.0 \mathrm{~kg} \mathrm{~B} / \mathrm{ha}$ ) levels on 
quality, economics an uptake of nutrients in mustard [Brassica juncea (L.) Czern \& Coss]. Results revealed that application of $60 \mathrm{~kg} \mathrm{~S} /$ ha gave significantly higher seed yield, economics, oil yield, protein yield and nutrients uptake (kg/ha) than control, 20 and $40 \mathrm{~kg} \mathrm{~S} /$ ha during experimental years. The application of $1.0 \mathrm{~kg} \mathrm{~B} /$ ha significantly increased seed yield, economics, oil yield, protein yield and nutrients uptake ( $\mathrm{kg} / \mathrm{ha}$ ) of mustard over control and $0.5 \mathrm{~kg} \mathrm{~B} / \mathrm{ha}[37,38]$.

\section{Conclusion}

Cultivation of fertilizer responsive and high yielding varieties of crops throughout the year causes serious depletion of the limited micronutrient reserve in soils which is subsequently manifested in the form of showing a deficiency of micronutrient and reduction of crop yield. Split applications of boron either through soil or foliar sprays were somewhat more effective than a single boron application for mustard and potato. However, a single late application of boron was more effective than early or split applications in increasing wheat yields on boron-deficient soils.

\section{References}

1. Mengel K, Kirkby EA (1987) Principles of Plant Nutrition. International Potash Institute, Switzerland.

2. Marschner H (1995) Mineral nutrition of higher plants. (2 $\left.{ }^{\text {nd }} E d n\right)$. Academic Press. London. UK, pp. 889.

3. Miwa K, Fujiwara T (2010) Boron transport in plants: co-ordinated regulation of transporters. Annals of Botany 105(7): 1103-1108.

4. Mandal B, Adhikari TK, De DK (1993) Effect of lime and organic matter application on the availability of added boron in acidic s alluvial soils. Common Soil Sci. Plant Anal 24(15-16): 1925-1935.

5. Hossain MA, Jahiruddin M, Khatun F (2011) Effect of boron on yield and mineral nutrition of mustard (Brassica napus). Bangladesh-Journal-ofAgricultural-Research 36(1): 63-73.

6. Mezuman U, Karen R (1981) Boron adsorption by soils using a phenomenological adsorption equation. Soil Sci Soc Am J 45(4): 722726.

7. Bloesch PM, LC Bell, JD Hughes (1987) Adsorption and desorption of boron by goethite. Aust J Soil Res 25(4): 377-390.

8. Ismail C, Volkar R (1997) Boron deficiency-induced impairments of cellular functions in plants. Plant and Soil 193(1): 71-83.

9. Parr AJ, Loughmann BC (1983) Metals and Micronutrients Uptake and Utilization by Plants. Academic Press, New York, USA, pp. 87-107.

10. Sharma PN, Tanuja R (1991) Indian J Exptl Biol 29(10): 967-970.

11. Goldberg S (1997) Reactions of boron with soils. Plant and Soil 193(1): $35-48$.

12. Datta SP, Bhadoria PBS, Kar S (1998) Availability of Extractable Boron in Some Acid Soils, West Bengal, India. Communications in Soil Science and Plant Analysis 2285-2306.

13. Sarkar D, Mandal B, Mazumdar D (2008b) Plant availability of boron in acid soils as assessed by different extractants. Journal of Plant Nutrition and Soil Science 171(2): 249-254.

14. Sarkar D, Mandal B, Kundu MC, Bhat JC (2008a) Soil properties influence distribution of extractable boron in soil profile. Communications in Soil Science and Plant Analysis 39(15-16): 2319-2332.
15. Berger KC, Troug E (1945) Boron availability in relation to soil reaction and organic matter content. Soil Science Society of America Proceedings 10: 113-116.

16. Olsen RV, Berger KC (1946) Boron fixation as influenced by PH, organic matter content and other factors. Soil Science Society of America Proceedings 11: 216-220.

17. Parks WL, White JL (1952) Boron retention by clay and humus systems saturated with various cations. Soil Science Society of America Proceedings 16: 298-300.

18. Sakal R, Sinha RB, Singh AP (1990) Response of chickpea to boron application on calcareous soils. International Chickpea Newsletter 22: 28-29.

19. Rerkasem B, Bell RW, Lodkaew S, Loneragan JF (1993). Boron deficiency in soybean, peanut and black gram: Symptoms in seeds and differences among soybean cultivars in susceptibility to boron deficiencies. Plant and Soil 150(2): 289-294

20. Kalyani RR, Sree Devi V, Satyanarayana NR, M Rao (1993) Effect of foliar application of boron on crop growth and yield of Pigonpea (Cajanus Cajan L.) (Mill sp). Indian J PL Ph (4): 223 -226.

21. Bose U S, Tripathi S K (1996) Crop Res 12(1): 61-64.

22. Sathya S, (2006) M Sc (Ag) Thesis, Agricultural College and Research Institute, Madurai.

23. Kumar A, Singh KP, Singh RP, Sarkar AK (1996) Response of groundnut to boron application in acid sedimentary soil. J Indian Soc Soil Sci 44: 178-179.

24. Lalit Bhatt B (2004) Prog Hort 36(2): 331-334.

25. Rego TJ, Wani SP, Sahrawat KL, Pardhasaradhi G (2005) Macrobenefits from boron, zinc and sulfur application in Indian SAT: A step for Grey to Green Revolution in agriculture. Global Theme on Agroecosystems Report no. 16. Patancheru 502 324, Andhra Pradesh, India: International Crops Research Institute for the Semi-Arid Tropics, pp. 24.

26. Mollah MRA, Khatun MR, Islam MJ, Rahim MA, Khalequzzaman KM (2005) Effect of Boron fertilization on yield of mustard varieties. International-Journal-of-Sustainable-Agricultural-Technology 1(4): 77-81.

27. Rana KS, Rana DS, Gautam RC (2005) Influence of phosphorus, sulphur and boron on growth, yield, nutrient uptake and economics of Indian mustard (Brassica juncea) under rainfed conditions. Indian-Journal-ofAgronomy 50(4): 314-316.

28. Sarkar D, Mandal B, Kundu MK (2007) Increasing use efficiency of boron fertilizers by researching the time and methods of application for crops in India. Plant and Soil 301: 77-85.

29. Singh S, chopra N, Reddy KS, leelavati (2012) Influences of sulphur and boron on yield attributes and yield of soybean Crop Res 44(3): 318321.

30. Nadian H, Najarzadegan R, Saeid A, Gharineh MH, Siadat A, et al. (2010) Effects of boron and sulphur application on yield and yield components of Brassica napus L. in a calcareous soil. World Applied Sciences Journal 11(1): 89-95.

31. Mathew J, George S, Indira M (2013) Effect of sulphur and boron on the performance of sesame (Sesamum indicum L) in onattukara sand soil of Kerala, India. Indian J Agric Res 47(3): 214-219.

32. Tandon HLS (1990) Fertilizer recommendations for oilseed crops. A guide book. Fertilizer development and consultation organization, New Delhi, India.

33. Sud KC, Sharma RC, Verma BC (1996) Evaluation of levels and sources of sulphur on potato nutrition in Shimla Hills. Journal of the Indian Potato Association 23: 134-138. 
34. Sarker SK, Chowdhury MAH, Zakir HM (2002) Sulphur and boron fertilizer on yield, quality and nutrient upatake uptake by Bangladesh soybean. Online Journal of Biological Sciences 2(11): 729-733.

35. Karthikeyan K, Shukla LM (2008) Effect of Boron - Sulphur Interaction on their Uptake and Quality Parameters of Mustard (Brassica juncea L.) and Sunflower (Helianthus annuus L.) Journal of the Indian Society of Soil Science 56(2): 225-230.

36. Devi KN, Singh LNK, Singh MS, Singh SB, Singh KK, et al. (2012) Influence of sulphur and boron fertilization on yield, quality, nutrient uptake and economics of soybean (Glycine max) under upland conditions. J Agricultural Science 4(4): 1-10.

37. Verma CK, Prasad K, Yadav DD (2012) Studies on response of sulphur, zinc and boron levels on yield, economics and nutrients uptake of mustard [Brassica juncea(L.) Czern \& Coss] Crop Res 44(1\&2): 75-78.

38. Sakal R, Singh AP (1995) Boron research and agricultural production. In: H. L. S. Tandon (Edn) Micronutrient and Agricultural Production $83-$ 114. 